\title{
Ainedidaktiikan moninaisuus ja erityisyys
}

Ainedidaktiikka-lehdellä on meneillään jo neljäs vuosikerta. Lehti aloitti toimintansa kolmen päätoimittajan ja monialaisen toimituskunnan yhteistyönä syksyllä 2017. Olimme tunnistaneet valtakunnallisesti merkittävän aukon tutkimusperustaisen, eri tiedonalojen erityisiä kysymyksiä pohtivan julkaisun tarpeellisuuden opetuksen ja oppimisen tutkimuksen kehittämisessä. Lehti vastaanotettiin mielenkiinnolla ja siihen tarjottiin heti innokkaasti ainedidaktiikan alaa käsitteleviä käsikirjoituksia, mikä osoitti arvioidun tilanteen oikeaksi. Olemme julkaisseet yhteensä jo 26 vertaisarvioitua artikkelia. Olemme pyrkineet pitämään julkaisun tason korkeana; läheskään kaikkia tarjottuja artikkeleita ei ole hyväksytty. Vertaisarvioijina ovat toimineet pääosin alansa eturivin edustajat.

Julkaistut artikkelit ovat käsitelleet usein tiettyyn oppiaineeseen liittyviä kysymyksiä, kuten matematiikan tai historian oppimisen ja opettamisen erityiskysymyksiä. Tiedonalojen problematiikkaa on tarkasteltu artikkeleissa myös erilaisin eheyttävin näkökulmin, joista erityisesti monilukutaito näyttää olleen ajankohtaista. Julkaistujen artikkeleiden tutkimusteemojen retrospektiivinen tarkastelu heijastaa ainedidaktisen tutkimusperustaisen opetuksen kehittämisen ydinajatuksia. Yhtäältä tarvitsemme edelleen tutkittua ymmärrystä oppiainekohtaisista kysymyksistä moninaisten tiedonalojen erityisyydet huomioiden. Toisaalta tarvitsemme myös tutkimustietoa siitä, miten kullekin oppiaineelle tai tiedonalalle ominaiset näkökulmat maailman tutkimisessa ja ymmärtämisessä saatetaan keskustelemaan keskenään, kun oppiminen ja opetus laajenevat oppiainerajat ylittäväksi osaamiseksi. Voidaan siten todeta, että lehti on teemoina tavoittanut nämä molemmat ainedidaktisen tutkimuksen suunnat ja saavuttanut vakiintuneen asemansa tieteen kentässä JUFO-luokiteltuna journaalina. Lehti on löytänyt säännöllisen lukijakuntansa. Käsikirjoituksia jätetään arvioitavaksi kasvavalla tahdilla. Käsillä oleva julkaisuvuosi on tähänastisista vilkkain. Julkaisutoimintamme laajenee kahden säännöllisesti ilmestyneen numeron lisäksi teemanumeroiksi, joita tullaan julkaisemaan kaksi kuluvana vuonna. Teemanumerot tulevat käsittelemään käsityökasvatusta ja ympäristökasvatusta. Toivottavasti ainedidaktiikan tutkijat hyödyntäisivät lehden artikkeleita tutkimus- ja opetustyössään 
Ainedidaktiikka 4(2) (2020)

sekä viittaisivat lehden artikkeleihin. Näin ainedidaktinen tieto välittyisi laajasti ja monipuolisesti alan opetuksen ja oppimisen tutkimukseen.

Lehden päätoimitus uusiutuu kuluvana vuonna. Jo tässä vaiheessa kiitämme yhteisesti ja lämpimästi kaikkia lehteen käsikirjoituksensa jättäneitä kirjoittajia ja niitä vertaisarvioineita arvioitsijoita erittäin arvokkaasta panoksestanne valtakunnallisessa keskustelussa ainedidaktisen tutkimuksen kehittämiseksi. On ollut ilo havaita, miten kirjoittajat ovat lähettäneet tekstejään ja arvioitsijat antaneet niistä kriittistä ja rakentavaa palautetta. Yhdessä olemme luoneet ja vakiinnuttaneet ainedidaktiikalle valtakunnallisen tutkimukseen perustuvan äänenkäyttäjän.

Kalle Juuti, Seija Kairavuori ja Arto Kallioniemi

Helsingin yliopisto, Kasvatustieteellinen tiedekunta 